\title{
Provocation
}

\section{Where's Elvis and Trump? Where's Godzilla and Gaga? Where's Bowie and Beyoncé? Popular cultures in Social and Cultural Geography, 2000-2020}

This provocation considers engagements with popular and media cultures in Social and Cultural Geography. I celebrate the journal's major achievement in creating a space for substantial empirical-theoretical consideration of popular and media cultures, notably via sustained work on popular geopolitics, postcolonial cultures, and subcultural scenes. However, I also note the absence of so many iconic figures and forms of popular culture. In short: where are Elvis, Trump, Aretha, Godzilla, Gaga, Bowie, Beyoncé, Micky Mouse, Father Christmas and countless others, and how might we understand their absence from the journal? I argue that engagements with popular and media cultures in Social and Cultural Geography have been weirdly coy, time-lagged and uneven. I call for more scholarship attuned to, and alive with, these affecting, life-changing, identity-defining, power-laden geographies.

\section{Preface: searching for popular cultures in Social and Cultural Geography, 2000-2020}

Try this game. It has occupied, entertained and challenged me for hours while writing this essay.

Step 1: Think of an iconic piece of popular culture. Perhaps a song, movie, television show, game, meme, character, technology, event, genre, scene, subculture, artist, artwork, social network, performer or celebrity. Perhaps something that matters to you. Perhaps something of life-changing, identity-defining, zeitgeist-shifting importance for many people, past or present, for better or worse.

Step 2: Go to the Social and Cultural Geography homepage and search for this thing, anywhere in the journal, from issue 1 to present, and see how many times it has been mentioned.

I wager that the answer will be 'none' or 'maybe once, but it is only a slight, momentary, glancing mention amid a discussion of something else'.

Step 3: Repeat

\section{Introduction}

Twenty years on from the inaugural issue of Social and Cultural Geography, this provocation considers the journal's engagement with, and accommodation of, popular and media cultures. This will entail a rather twofaced argument. On one hand, I want to celebrate the journal's major achievement in creating a space for substantial empirical-theoretical consideration of popular and media cultures, particularly through sustained lines of work on popular geopolitics, postcolonial cultures, and subcultural scenes. On the other hand, having played many rounds of the prefatory game, I want to note the absence of so many iconic figures and forms of popular culture. In short: where are Elvis, Trump, Aretha, Godzilla, Gaga, Bowie, Beyoncé, Micky Mouse, Father Christmas and countless others, and how might we understand their absence from the journal? I argue that engagements with popular and media cultures in Social and Cultural Geography have been peculiarly coy, time-lagged and uneven. I call for more scholarship attuned to, and alive with, these affecting, life-changing, identity-defining, power-laden geographies.

\section{Popular cultures in Social and Cultural Geography: a celebration}

Since the inaugural issue, more than 200 papers published in Social and Cultural Geography have featured explicit, extended discussion around the phrase 'popular culture'. This rich, continuing line of empiricaltheoretical work has extended the journal's foundational concern to foster "innovative ways to think through geographical ideas and open...up alternative vistas of study" (Gleeson et al, 2000, p.5), particularly via studies of material cultures, consumption and commodification in relation to diverse, global forms of popular and media culture (Jackson, 2000).

In practice, since 2000, the journal has featured research on an astonishing and vibrant array of popular and media cultures, spanning all manner of popular cultural discourses, genres, media, moments, events and spaces. The journal has come to be the home for exciting, international scholarship on topics as diverse as 
geographies of popular music (Anderson, 2004; Liu and Cai, 2014; Milburn, 2017), cinemas and cinema-going (Halus, 2017; Ozduzen, 2017), comix and graphic novels (Dittmer, 2014), videogames and gamers (Shaw, 2010; Shaw and Sharp, 2013; Jones and Osborne, 2018), literature and poetry (Yap, 2011), sports fandom (Conner, 2014; Lawrence, 2016), children's toys, trends and enthusiasms (Horton, 2010), hobbyist collecting and wargaming (Yarwood, 2015), online spaces, social media, memes and videos-gone-viral (Lancione, 2014), adverts and anthropomorphic animals (Burton and Collins, 2014), celebrities (McNamara, 2008) and zombies (May 2010). Looking back over this body of work, once can trace an increasingly complex, nuanced and challenging apprehension of interrelated popular cultural materialities, identities, spaces, styles, fashions, politics, communities and exclusions.

We should celebrate, then, the major achievement of Social and Cultural Geography in constituting a supportive - and unprecedented - space for empirical-theoretical consideration of geographies of popular culture and media. In particular, I want to celebrate three major lines of scholarship - of international, interdisciplinary significance - which have developed through the journal. First, the journal has featured an important strand of work on popular geopolitics, with papers critically exploring interplays between popular cultural producers, industries, texts, materialities and audiences in processes of identity formation, nationhood and the perpetuation of geopoliticised ideologies, norms, myths and discourses, past and present (Dittmer and Larsen, 2007). In this vein, authors have provided powerful, critical geopolitical readings of comic books (Dittmer and Larsen, 2007), Tintin adventure stories (Dunnett, 2009), television dramas (Saunders, 2017), film genres (Halus, 2017), tourist sites (Mostafanezhad and Promburom, 2018), and animated comedies (Thorogood, 2018). Work in the journal has thus been important in constituting an increasingly internationalised and careful, relational, polyvocal, reflective, empirically-grounded critical geopolitics, attuned to the complex materialities, relationalities of popular and media cultures (Dittmer, 2013; Dittmer and Dodds, 2013; Dittmer and Gray, 2010).

Second, relatedly, Social and Cultural Geography authors have made important contributions to theorisations of postcolonial geographies and cultures. A range of papers have provided haunting, troubling evocations of the roles of popular and media cultures in naturalising colonialist discourses and power relations, in constituting or excluding claims to identity, truth, belonging and land, in effacing subaltern memories, voices and knowledges, but also in offering more hopeful sites for countering colonialist power/discourses. For example, authors have extended and grounded postcolonial theories through studies of land claims (Ellmor, 2003), colonially-rooted spatial imaginaries in cinematic representations (van Gent and Jaffe, 2016), enduring colonialist ideals in leisure and sport (Moser, 2010), exoticised images of women's bodies (Maher and Lafferty, 2014), and the continuing circulation of orientalist representastion via travel writing and tourist guides (Tavares and Brossaeau, 2006), news reportage (Doboš, 2018), sci-fi and genre fantasy (Balfe, 2007), and place promotion (Dunn, 2003). In so doing, Social and Cultural Geography authors have contributed significantly to the task of folding diverse, emergent imaginative geographies into understandings of (post)colonialism and orientalism (Sharp, 2009).

Third, Social and Cultural Geography authors have provided many rich qualitative and ethnographic accounts of the constitutive roles of popular culture for local and global scenes and subcultures. The journal has published landmark papers on geographies of popular and vernacular music via diverse, careful studies of, for example, Francophone folk (Revill, 2005) Goan trance (Saldanha, 2005), Guangzhou underground (Liu and Cai, 2014), Lisbon dance (Nofre et al, 2016) and London Grime scenes (Woods, 2017). Notably, too, the journal has published important papers exploring intersections of popular and media cultures with contemporary geographies of sexualities (Podmore, 2006; Muller, 2007; Gorman-Murray, 2011; Misgav and Johnson, 2014), family, parenting and intergenerationality (Holloway and Valentine, 2001; Madge and O'Connor, 2006; Chouinard, 2009), tourism (Johnson, 2004) and disabilities (Davidson, 2008). The journal has thus become an important site of encounter between social and popular cultural geographies, and between social and cultural geographers.

\section{Absences: unmentioned popular cultures}

And yet, for all of this fantastic work, I find myself troubled by the coverage of popular culture and media in Social and Cultural Geography. I can perhaps make this point most vividly by presenting a list of things, 
people and phenomena which, at time of writing, have never been mentioned in Social and Cultural Geography, or have been mentioned just once in an incidental remark (see figure $1^{1}$ ).

\section{Figure 1 Things never mentioned in Social and Cultural Geography ${ }^{2}$}

Aan, Abba, Chinua Achebe, acid house, Carlos Acosta, Chimamanda Ngozi Adichie, Adidas, Muhammad Ali, Amar Chitra Katha, Manal alSharif, the Amen Break, American Girl, Maya Angelou, Anohni, Apple ${ }^{3}$, Louis Armstrong, Neil Armstrong, Atkins Diet, Jane Austen, Banksy, Barbie4, Jean-Michel Basquiat, Bauhaus, The Beano, Mary Beard, the Beckhams, Ben and Jerry's, Alan Bennett, Beyoncé, Bhangra, Asha Bhosle, SRK, Madhuri Dixit (or any iconic Bollywood performers and singers), Monsieur Bibendum, Justin Bieber, Bikini Kill, \#blacklivesmatter, \#BlackOut, Leigh Bowery, David Bowie, The Brady Bunch, Felix Bressart, Brokeback Mountain, the Brontë sisters, James Brown, bubblegum, buddyboowaggytails, Gordon Burn, CaELiKe, Candy Crush Saga, Nancy Cárdenas, Roberto Carlos (either one), Anthony Cartwright, Casablanca, Cheers, Chibi Maruko-chan, Dr. Slump (or any Japanese manga TV series), Chicago house, Agatha Christie, Chunwan, Xinwen Lianbo (or any China Central TV broadcast), Marie Claire, Hillary Clinton, The Clock, Coco, John Coltrane, Douglas Coupland, Brian Cox, Crass, Patrisse Cullors, Cuna de Lobos, La Usurpadora (or any Mexican telenovela), Miley Cyrus, Daft Punk, Roald Dahl, Dan TDM, Ryan Toy Review, PewDiePie (or any of the 100 most subscribed Youtube channels), Diary Milk, Angela Davis, Dawson's Creek, d-beat, Death Note, Ellen DeGeneres, Cruella de Vil, Detroit techno, Fyodor Dostoyevsky, Dracula, Dragon Ball Z, Dr Who, Marcel Duchamp, Dunkin' Donuts, ebay, edgelords, David Eggers, Barbara Ehrenreich, 88, TS Eliot, Missy 'Misdemeanour' Elliott, Emily the Strange, Tracey Emin, emojis, Epic Sax Guy, Eurovision, everydayfeminism, @EverydaySexism, The Exorcist, \#fail, 'fake news', fan fiction, Father Christmas (and Rudolph the Red-Nosed Reindeer), Feminist Frequency, @fergusgeocat, Elena Ferrante, Fifty Shades of Grey, Fitbit, Ella Fitzgerald, Forensic Architecture, Fortnite, 4chan, 420, 555, 55555, FML, Fox News, Anne Frank, Frankenstein, Aretha Franklin, Joan Jett, Mia X, Krystal Wakem, Kara Walker, Friends, Frozen, Fuleco, Lady Gaga, Neil Gaiman, Alicia Garza, Poli Genova, Greta ${ }^{5}$ Garbo, Marilyn Monroe, Marlene Dietrich, Joe DiMaggio, Marlon Brando, James Dean, Grace Kelly, Jean Harlow, Gene Kelly, Fred Astaire, Ginger Rogers, Rita Hayworth, Lauren Bacall, Katherine Hepburn, Lana Turner, Bette Davis, Ghost World, GI Joe, Gilbert and George, The Girl with the Dragon Tattoo, Godzilla, Pulgasari, Minilla (or any Kaiju), Goldie (either one), Gone with the Wind, Good Night, Little Ones!, Masha and the Bear (or any Russian children's television), Goodnight Moon, googling, Antony Gormley, Gossip, Hermione Granger, Grease, Germaine Greer, Grindr, grunge, Guerrilla Girls, The Gummy Bear Song, Andreas Gursky, Rob Halford, Hamilton, The Handmaid's Tale, Kathleen Hanna, Gretchen Phillips, Cibo Matto, Leslie Feinberg, Faith Ringgold, Mr. Lady, Laura Cottingham, Mab Segrest, The Butchies (man!), Keith Haring, PJ Harvey, Stephen Hawking, heavy metal, Hello Kitty, Ernest Hemingway, Audrey Hepburn, Damien Hirst, Alfred Hitchcock, Billie Holiday, Alan Hollinghurst, +HOLYPARISHOFDOOM + , Hoshimogga, Howlin' Wolf, The Hunger Games, Hsu Fu Chi, IMDB, Invader (or Space Invaders), Tony lommi, IPL, Italo Disco, Italo House or Italo Horror, It Happened One Night, iTunes, jackin' house, Mahalia Jackson, Michael Jackson, Marsha P. Johnson, JAY-Z, J-Pop, K-Pop or C-Pop, Colin Kapernick, Anish Kapoor, the Kardashians, Kasautii Zindagii Kay, Kyunki Saas Bhi Kabhi Bahu Thi (or any Hindi serial), Kitsutsuki to Ame, Kermit the frog (or any Muppets), Stephen King, Kayleigh Kitson, Miss Kiyami, Chuck Klosterman, Kraftwerk, Krispy Kreme, Milan Kundera ${ }^{6}$ Fela Kuti, Lady Bird, Hedy Lamarr, LCD Soundsystem, Lower 48, the Association, Sun Ra, Gil Scott Heron!, Jeff 'The Dude' Lebowski, Bruce Lee, Spike Lee, Lego, Ursula le Guin, Andrea Levy, Little Richard, lip gloss, Andrew Lloyd Webber, lol, \#lolcats, Audre Lorde, M\&Ms, Macbeth, Madonna, Mahabharat, Bob Marley, Gabriel García Márquez, Ricky Martin, Haruki Marukami, Armistead Maupin, Val McDermid, Ronald McDonald, Steve McQueen (either one), mecha, Melt Banana, \#metoo, Midnight, Minecraft, Minor Threat, MLB, Moana, Moomins, Alan Moore, Michael Moore, Motown, Micky Mouse, milkshake, Ms., My Beautiful Laundrette, Naruto, Nazia and Zoheb, Willie Nelson, Nestlé milk formula, Netta, NFL, Nike, Nikoli, NWA, Michelle Obama, Occidentali's Karma, Chris Ofili, Georgia O'Keeffe, OMG, Joshua Oppenheimer, Joe Orton, Pac-Man, Orhan Pamuk, Panini, Emmeline Pankhurst, panto, Paralympics, Parle G, Martin Parr, John Peel, Pelé, Peppa Pig, Carl Perkins, Perviy Kanal, Pablo Picasso, Pillsbury Dough Boy, Harold Pinter, Pixar, Pokémon, Pokémon Go, Popbitch, the Pope, Mary Poppins, Powerpuff Girls, Prince, P-Square, Pravda, Elvis Presley, Public Enemy, Princess Peach, Philip Pullman, Punxsutawney Phil, Pussy Riot, Vladimir Putin7, QQ, quiz shows, the Ramones, Rana Plaza, RCLBeauty101, @realgrumpycat, reality television, Retroblasting, Ringu, Riot Grrrl, Sylvia Rivera, Rock Around the Clock, Rocky, Romanthony, Romeo and Juliet, the Royal Family, Joe Sacco, Saiyūki, Sanjay's Super Team, Arnold Schwarzenegger, Verka Seduchka, Maurice Sendak, Sesame Street, Dr. Seuss, the Sex Pistols, Cindy Sherman, Sia, the Simpsons, sitcoms, sjw, SmartBrownGirl, Smash Hits, Zadie Smith, Smokey Bear, Smoothiefreak, Snickers, Snopes, snowflakes, The Snow Man (or snowmen generally), Snow White, soap opera, soapies, Aleksandr Solzhenitsyn, Britney Spears, the Spice Girls, Spiderman, Mr. Spock, Stand-up comedy, Ziggy Stardust, Star Wars, Stax, \#staywoke, Studio 54, Studio Ghibli, Donna Summer, SunnO))), Super Mario, IISuperwomanll, Taylor Swift, Sylvester, Donna Tartt, TCGs, Tetris, Tieta, Roque Santeiro (or any Brazilian telenovelas), Wolfgang Tillmans, Tinder, To Kill a

\footnotetext{
${ }^{1}$ See also Horton (2018) for a similar, more specialised list of popular cultural icons which have been absent from recent geographical work with children and young people.

${ }^{2}$ Searches were carried out in May 2018. Items included here have either: (i) never been mentioned anywhere in the journal; or (ii) only mentioned once or twice in a fleeting, incidental comment amid a discussion of something else. ${ }^{3}$ Neither the tech or record company have been mentioned. However, there have been 18 mentions of actual or metaphoric apples.

${ }^{4}$ I am not counting mentions in Horton (2010) which called for further research on iconic examples of children and young people's popular cultures.

${ }^{5}$ For the avoidance of doubt, non-alphabetical runs of names in the list are intentional popular cultural references. Well done if you can identify any of these.

${ }^{6}$ Ironically only mentioned in Kinsley's (2016) critique that geographers have tended to "aspire to an 'unbearable lightness' and not 'fifty shades' of cultural geography".

${ }^{7}$ Last mentioned in 2004.
} 
Mockingbird, tokusatsu, Leo Tolstoy, Tony the Tiger, Topps, Toy Story, trolling, Trolls, Donald Trump ${ }^{8}$, @realDonaldTrump, Tropicália, Will Tura, Uplift, Vardi Wala Gunda, Velvet Underground, VGTRK, Vogue, Alice Walker, Wallace and Gromit, Gillian Wearing, Harvey Weinstein, Ai Weiwei, West Wing, Vivienne Westwood, the Wheels on the Bus, Wikipedia, Oscar Wilde, Serena Williams, Jacqueline Wilson, Oprah Winfrey, Winnie-the-Pooh, Jeanette Winterson, The Wire, Wolf Warrior 2, Wonder Woman, Wrestlemania, Conchita Wurst, Wu-Tang Clan, The X Factor, Fei Xiang, Gao Xingjian, XKCD, Cáo Xuěqín, YMO, Yuya, Zakumi, Malala Yousafzai, Zarkkor!, Zelda, Zumba, Zwarte Piet, zxcvbnm

The list in figure 1 is deliberately excessive (though, inevitably, geographically, culturally and historically situated). Yet it is only indicative and could also be extended endlessly and fractally by readers' engagements with the prefatory game. While Social and Cultural Geography has constituted a major body of work on geographies of popular culture and media, it is a body of work overwhelmingly characterised by perplexing high profile absences. It is puzzling to have a journal which, in many ways, foregrounds popular and media cultures yet has never mentioned so many important figures and things: where are Elvis, Trump, Gaga, Godzilla, Beyoncé, Bowie, Bollywood, Disney, telenovelas, and so much else?

Millions of people care about each of the things listed in figure 1. Many items listed are the most widelyrecognised, widely-consumed, critically-acclaimed or notorious examples of their kind. However, twenty years of scholarship in Social and Cultural Geography has said nothing about all this stuff. Barnett's (2015, unpaginated) quip that social and cultural geography has seemed to "be constituted as if...The Beatles, Elvis, or The Supremes never happened" has a ring of truth. To schematise and evidence this point further, consider that Social and Cultural Geography authors have discussed: none of the 20 all-time most viewed television series in either the UK and USA; only three ${ }^{9}$ of the 100 all-time top grossing English language films ${ }^{10}$ and 91 winners of Academy Award for Best Picture; none of the 50 all-time top-grossing movies in languages other than English; only one song and one artist ${ }^{11}$ from the 272 songs which have been bought or downloaded more than 5 million times; only one of the 100 all-time most viewed Youtube videos ${ }^{12}$; none of the 50 most shared internet memes and none of the 100 most subscribed YouTube channels; and only three of the 50 all-time top grossing video games ${ }^{13}$.

One might critique these absences in a number of ways. They might suggest a disinclination to commit to scholarly engagements with big, public, popular or populist cultures. Of course, authors cannot be expected to cover every key trend or happening in popular and media culture, but Social and Cultural Geography does seem to have had a knack of missing all kinds of iconic, astonishing, thought-provoking, defining stuff in and of contemporary popular and media cultures. So many important popular cultural moments, which matter(ed) profoundly in the lives of millions of people, have passed without acknowledgment in the work of social and cultural geographers. Critics like Kinsley (2016) are inclined to see these absences as a matter of taste, particularly classed normative assumptions about what matters. Noting "a relative paucity of work in geography on 'low', 'mainstream', 'popular' or 'vernacular' cultural geography" (p.793), Kinsley argues that, through our work, geographers "are implicated in...normative judgements, and...we imply a form of taste concerning what is worthy of study by what we do not write about just as much as that which we do" (p.794). I agree, but would also argue that this argument is complicated by the aforementioned presence of rich empirical work in Social and Cultural Geography dealing with popular geopolitics, postcolonial cultures, and subcultural scenes. I would also note that the journal's coverage of more 'literary', 'artistic', 'esteemed' forms of 'high culture' is, if anything, even more limited. For example, to date, Social and Cultural Geography

\footnotetext{
${ }^{8}$ Since this paper was drafted, he has been mentioned, briefly, in a few new papers. But still, I think the point stands that it is remarkable that he did not figure in the journal until late 2018.

${ }^{9}$ Since you ask, they are Chicago (Mathews, 2010), Hurt Locker (Aitken, 2012), and Lord of the Rings (Anderson, 2013 perhaps tellingly in a Special Issue on 'marginalia in research'). A further 12 titles were fleetingly, and sometimes incongruously, mentioned in the context of something else.

${ }^{10}$ Both adjusted for, and unadjusted for, inflation. Yes, I spent far too long doing this.

11 Psy's Gangnam Style (Wilkinson, 2017) and the Beatles (Boland, 2008; Milburn, 2017), respectively.

12 Wilkinson (2017) on Psy's Gangnam Style, again.

${ }^{13}$ Call of Duty: Modern Warfare 2 (Shaw, 2010), Call of Duty: Modern Warfare 3 (Shaw and Sharp, 2013) and Grand Theft Auto (Thorogood, 2018) (perhaps suggesting a tendency to focus on lurid, violent, sensationalised forms of gaming? I am not an expert though. Please don't quote me on this.)
} 
authors have discussed: only seven of the 48 winners of the Booker Prize for Fiction ${ }^{14}$; only seven of the 114 winners of the Nobel Prize for Literature ${ }^{15}$; just one of the 34 winners of the Turner Prize 'for outstanding work in the visual arts'16; and none of the winners of the International Booker Prize for 'quality fiction in translation', or the Women's Prize for Fiction for 'excellence, originality and accessibility in writing by women throughout the world'. Just one of the 38 winners of the PEN/Faulkner Award for fiction, and five of the 91 novelists awarded the Pulitzer Prize, have been (very briefly) cited in the journal. Nevertheless, geographers must take care not to perpetuate normative classed assumptions about popular and media culture discussed (or not) in their work.

The absences noted in figure 1 also imply a systematically limited engagement with non-Anglophone popular and media cultures, particularly those lived and loved outside the UK and North America. It is easy to identify all manner of major, iconic, defining non-Anglophone popular and media cultures which are unacknowledged in Social and Cultural Geography. This is perhaps unsurprising given the language and institutional backgrounds of most of the journal's authors to date, but should challenge us - and the journal - to be more internationalist in outlook. How might we foster more writing, thinking and research about popular and media cultures elsewhere? Also troubling is a further set of absences suggested by figure 1: is there a sense that the journal's coverage of popular and media cultures has tended to marginalise popular cultural figures and events which have been specifically important, transformative and emancipatory for many women, LGBTQ+ communities and African-American audiences? Again, geographers should take care not to unwittingly reproduce an exclusionary (male, white British/American, Anglophone, heteronormative, ableist) canon of popular culture and media through their work. Moreover, the absences in figure 1 might imply the peculiar, marginalised, 'passé' status of representations, meanings, texts and audiences within social and cultural geography over the last two decades. Is there a sense that, a broadly nonrepresentational theoretical and methodological turn away from 'new cultural geographies' has effectively marginalised the formative theoretical influences, research methods and objects of enquiry which classically constituted 'new cultural geographies'? Or, why has recent scholarship in Social and Cultural Geography seemed disinclined to engage with music, film, television, subcultures, performance, celebrity and material cultures in the ways anticipated at the journal's outset?

\section{Geographies of popular culture and media could be less coy, time-lagged and uneven}

The development of this provocation leads me to three conclusions. First, geographical engagements with popular culture and media could be less coy. Reflecting on two decades of scholarship in Social and Cultural Geography I am struck by the way in which most authors have avoided direct engagement with popular and media cultures unless that encounter is legitimised via discussion of something else. Typically, then, popular and media cultures have only been studied through the prism of some other, 'big', 'proper' legitimising set of questions (geopolitics, postcolonialism, urban social geographies). Otherwise, popular cultures are barely acknowledged, except via fleeting, glancing, incidental mentions in the context of something else. I this coyness profoundly limits geographers' ability to comment on, engage with, or intervene in contemporary cultures and cultural politics.

Second, geographical work on popular and media cultures could be much less time-lagged. I find that scholarship in Social and Cultural Geography has tended to lag years - decades, even - behind developments in contemporary popular and media cultures. Typically, it seems to take at least 10-20 years for popular cultural phenomena to be written about in Social and Cultural Geography. This time lag is perhaps most marked in the journal's coverage of the constitutive roles of social media and new technologies in contemporary popular cultures. As Rose (2016) argues, work by social and cultural geographers has barely kept pace with the proliferation of new, dynamic, multiplatform digital popular cultures and social media.

\footnotetext{
${ }^{14}$ V.S. Naipaul, William Golding, Salman Rushdie, Roddy Doyle, Arundhati Roy, J.M. Coetzee and Margaret Atwood. Notably, these authors were cited $10-40$ years after publication of their Booker-winning novel. Also, no winner since 2000 has ever been mentioned in the journal.

${ }^{15}$ Henri Bergson, William Golding, Derek Walcott, Seamus Heaney, J.M.Coetzee, Doris Lessing and Bob Dylan. A further 12 Nobel Laureates have been fleetingly and incidentally cited elsewhere.

${ }^{16}$ The landscape artist Richard Long (Morris and Cant, 2006; Ramsden, 2017). Three others (Rachel Whiteread, Gillian Wearing, Grayson Perry) were very briefly and incidentally mentioned in other papers.
} 
While Facebook, Twitter and Instagram are increasingly covered in Social and Cultural Geography, and there have been notable recent attempts to include discussions of screens and smartphones in research on diverse topics, coverage of a vast range of international and emergent social media and technologies has been minimal to date ${ }^{17}$.

Third, above all, I find the coverage of popular and media cultures in Social and Cultural Geography peculiarly uneven. By this, I mean the journal has afforded rich, leading work on some aspects of popular geopolitics, postcolonial cultures and urban subcultures - and definitive substantive pieces on, for example, Captain Canuck, zombies, femmes fatale in Czech cinema, and playful more-than-human actants in Tokyo - yet there are so many striking absences elsewhere. Pockets of leading work on specific aspects of popular and media cultures are juxtaposed with work in which, overwhelmingly, people's popular cultural lives and loves go entirely unregistered. When reading new research published in Social and Cultural Geography, one can never quite predict which popular and media cultures will be conspicuously present and which will be conspicuously absent. So I call for a social and cultural geographers to develop a wider repertoire of practices and habits to bring their scholarship, more consistently, into closer conversation with popular and media cultures from Aan to zxcrbnm and everything inbetween.

\section{References}

Anderson, Ben (2004) Recorded music and practices of remembering, Social and Cultural Geography 5: 1

Azaryahu, Moaz (2006) The beach at the end of the world: Eilat in Israeli popular culture, Social and Cultural Geography 6: 1

Balfe, Myles (2004) Incredible geographies? Orientalism and Genre Fantasy, Social and Cultural Geography 5:1

Burton, Lauren and Collins, Francis (2014) Mediated animal geographies: symbolism, manipulation and the imaginary in advertising, Social and Cultural Geography 16:3

Caprotti, Federico and Kaïka, Maria (2008) Producing the ideal fascist landscape: nature, materiality and the cinematic representation of land reclamation in the Pontine Marshes, Social and Cultural Geography 9: 6

Chouinard, Vera (2009) Placing the 'mad woman': troubling cultural representations of being a woman with mental illness in Girl Interrupted. Social and Cultural Geography 10:7 791-804

Conner, Neil (2014) Global cultural flows and the routes of identity: the imagined worlds of Celtic FC, Social and Cultural Geography 15:5

Davidson, Joyce (2008) Autistic culture online: virtual communication and cultural expression on the spectrum. Social and Cultural Geography, 9: 7

Dittmer, Jason (2014) Narrating urban assemblages-Chris Ware and Building Stories, Social and Cultural Geography 15: 5

Dittmer, Jason and Larsen, Soren (2007) Captain Canuck, audience response, and the project of Canadian nationalism, Social and Cultural Geography 8: 5

Dittmer, Jason (2013a). Geopolitical assemblages and complexity. Progress in Human Geography, 38(3), 1-17.

Dittmer, Jason and Dodds, Klaus (2013). The geopolitical audience: Watching quantum of solace (2008) in London. Popular Communication, 11, 76-91.

Dittmer, Jason and Gray, Nicholas (2010). Popular geopolitics 2.0: Towards new methodologies of the everyday. Geography Compass, 4, 1664-1677

Doboš, Pavel (2018) Imaginative geographies of distant suffering: two cases of the Syrian Civil War on television, Social and Cultural Geography 19: 6

Dowling, Robyn (2005) Social and cultural geographies of Australia, Social \& Cultural Geography, 6:5, 767-77

\footnotetext{
${ }^{17}$ For example, social media platforms such as a WhatsApp, Reddit and Sina Weibo have only been mentioned fleetingly once; Snapchat and Pinterest have only been mentioned in Rose's (2016) call for more research on digital cultures; QQ, WeChat, VKontakte, Taringa, Linkedin and many others have never been mentioned. Technologies for delivering media content such as iTunes, Netflix and Spotify have thus far only been briefly mentioned, once each. All manner of apps, games and memes have never been mentioned in the journal. As a case in point, I still direct undergraduate students to Holloway and Valentine's (2001) paper on family ICT usage as a key resource for understanding geographies of digital and online media. Latterly, it has become clear that students find the language, technologies, assumptions, norms and practices articulated in the paper to be entirely alien, olde worlde and bizarre.
} 
Dunn, Kevin (2003) Using cultural geography to engage contested constructions of ethnicity and citizenship in Sydney, Social \& Cultural Geography, 4:2, 153-165

Dunnett, Oliver (2009) Identity and geopolitics in Hergé's Adventures of Tintin, Social and Cultural Geography 10: 5

Ellemor, Heidi (2003) White skin, black heart? 1 The politics of belonging and Native Title in Australia, Social \& Cultural Geography 4:2

Gleeson, Brendon, Katz, Cindi, Johnson, Nuala, Kitchin, Rob, Peake, Linda, Sibley, David and Valentine, Gill (2000) Editorial, Social and Cultural Geography 1(1), pp.5-7.

Gorman-Murray, Andrew (2011) 'This is disco-wonderland!' Gender, sexuality and the limits of gay domesticity on The Block, Social and Cultural Geography 12: 5

Halfacree, Keith (2009) 'Glow worms show the path we have to tread': the counterurbanisation of Vashti Bunyan, Social and Cultural Geography 10: 7

Halus, Matus (2017, online early) Love your neighbor: Nazi soldiers and Femmes Fatales in Czech cinema, Social and Cultural Geography

Hammett, Daniel (2009) Local beats to global rhythms: coloured student identity and negotiations of global cultural imports in Cape Town, South Africa, Social and Cultural Geography 10: 4

Holloway, Sarah and Valentine, Gill (2001) 'It's only as stupid as you are': Children's and adults' negotiation of ICT competence at home and at school, Social and Cultural Geography 2:1

Horton, John (2010) 'The best thing ever': how children's popular culture matters, Social and Cultural Geography 11: 4

Jackson, Peter (2000) Rematerializing social and cultural geography, Social and Cultural Geography 1:1

Johnson, Nuala (2004) Fictional journeys: paper landscapes, tourist trails and Dublin's literary texts, Social and Cultural Geography 5:1

Jones, Keith (2010) Music in factories: a twentieth-century technique for control of the productive self, Social and Cultural Geography 6:5

Jones, Phil and Osborne, Tess (2018, online early) Analysing virtual landscapes using postmemory, Social and Cultural Geography

Kinsley, Sam (2016) Vulgar geographies? Popular cultural geographies and technology, Social and Cultural Geography 17: 6

Lancione, Michele (2014) The spectacle of the poor. Or: 'Wow!! Awesome. Nice to know that people care!' , Social and Cultural Geography 15:7 [memes/Facebook video going viral]

Lawrence, Stefan (2016) 'We are the boys from the Black Country'! (Re)Imagining local, regional and spectator identities through fandom at Walsall Football Club, Social and Cultural Geography 17: 2

Liu, Chen and Cai, Xiaomei (2014) Performing Guangzhou and Guangzhou Ren: analysing popular music in Guangzhou, Social and Cultural Geography 15:7

Longhurst, Robyn (2016) Mothering, digital media and emotional geographies in Hamilton, Aotearoa New Zealand, Social and Cultural Geography 16:1

Madge, Clare and O'Connor, Henrietta (2006) Parenting gone wired: empowerment of new mothers on the internet? Social and Cultural Geography 7:2

Maher, Kristen and Lafferty, Megan (2014) White migrant masculinities in Thailand and the paradoxes of Western privilege, Social and Cultural Geography 15:4, 427-448

Mathews, Vanessa (2010) Set appeal: film space and urban redevelopment, Social and Cultural Geography 11:2

May, Jeff (2010) Zombie geographies and the undead city, Social and Cultural Geography 11:3

McNamara, Kim (2008) Publicising private lives: celebrities, image control and the reconfiguration of public space, Social and Cultural Geography 10:1

Mee, Kathleen and Dowling, Robyn (2003) Reading Idiot Box: Film reviews intertwining the social and cultural, Social and Cultural Geography 4:2

Milburn, Kevin (2017, online early) Rethinking music geography through the mainstream: a geographical analysis of Frank Sinatra, music and travel, Social and Cultural Geography

Mostafanezhad, Marya and Promburom, Tanya (2018) 'Lost in Thailand': the popular geopolitics of film-induced tourism in northern Thailand, Social and Cultural Geography 19:1

Moser, Sarah (2010) Creating citizens through play: the role of leisure in Indonesian nation-building, Social and Cultural Geography 19:1, 53-73

Muller, Tiffany (2007) 'Lesbian community' in Women's National Basketball Association (WNBA) spaces, Social and Cultural Geography 8:1

Ozduzen, Ozge (2017, online early) Cinema-going during the Gezi protests: claiming the right to the Emek movie theatre and Gezi Park, Social and Cultural Geography

Pottie-Sherman, Yolande and Wilkes, Rima (2016) Visual media and the construction of the benign Canadian border on National Geographic's Border Security, Social and Cultural Geography 17:1

Revill, George (2005) Vernacular culture and the place of folk music, Social and Cultural Geography 6:5 
Rose, Gillian (2016) 'cultural geography going viral' https://www.tandfonline.com/doi/full/10.1080/14649365.2015.1124913

Saldanha, Arun (2005) Trance and visibility at dawn: racial dynamics in Goa's rave scene, Social and Cultural Geography 6:5

Saunders, Robert (2017, online early) Geopolitical television at the (b)order: liminality, global politics, and worldbuilding in The Bridge, Social and Cultural Geography

Sharp, Jo (2009) Geographies of Postcolonialism. Sage: London

Shaw, Ian (2010) Playing war, Social and Cultural Geography 11:8 [video war games]

Shaw, lan and Sharp, Joanne (2013) Playing with the future: social irrealism and the politics of aesthetics, Social and Cultural Geography 14:3 [video games]

Tavareas, David and Brosseau, Marc (2006) The representation of Mongolia in contemporary travel writing: imaginative geographies of a travellers' frontier, Social and Cultural Geography 7:2, 299-317

Thorogood, Joe (2018, online early) Cartoon controversies and geopolitics: Archer, animators and audiences, Social and Cultural Geography

Tyner, James (2004) Self and space, resistance and discipline: a Foucauldian reading of George Orwell's 1984, Social and Cultural Geography 5:1

van Gent, Wouter and Jaffe, Rivke (2017) Normalizing urban inequality: cinematic imaginaries of difference in postcolonial Amsterdam, Social and Cultural Geography 18: 4

Woods, Orlando (2018) The digital subversion of urban space: power, performance and grime, Social and Cultural Geography

Yap, Erica (2011) Readers-in-conversations: a politics of reading in literary geographies, Social and Cultural Geography $12: 7$

Yarwood, Richard (2015) Miniaturisation and the representation of military geographies in recreational wargaming, Social and Cultural Geography 16:6 